\title{
Methane and carbon dioxide emission measurements in selected area of the Polish Western Carpathians
}

\author{
Marzena Mojżysz ${ }^{1}$, Adrianna Góra ${ }^{1,}$, , Henryk Sechman $^{1}$, Piotr Guzy ${ }^{1}$, and Anna Twaróg ${ }^{1}$ \\ ${ }^{1}$ AGH University of Science and Technology, Faculty of Geology, Geophysics and Environmental \\ Protection, Department of Fossil Fuels, 30 A. Mickiewicz Av., 30-059 Kraków, Poland
}

\begin{abstract}
The paper presents measurement results of methane and carbon dioxide emission in Western Carpathians. The investigations were carried out with application of static chamber method in 10 stations. An emission and dynamics of changes within methane and carbon dioxide concentrations were examined by measuring the emission directly from the land surface as well as after drilling an additional hole. In total, 40 gas samples were taken, which were then subjected to chromatographic analysis. The measurements of methane and carbon dioxide emission have not shown significant emission values of these gases. The average value of methane emission from soil to the atmosphere at selected measurement sites was $-0.451 \mathrm{mg}^{*} \mathrm{~m}^{-2 *} \mathrm{~d}^{-1}$, while the average methane emission with the use of the hole, equalled to $-0.361 \mathrm{mg}^{*} \mathrm{~m}^{-2 *} \mathrm{~d}^{-1}$. The changes of carbon dioxide concetration were opposite. Higher emission of this gas was showed due to its natural escaping to the atmosphere with an average concetration of $1829,3 \mathrm{mg}^{*} \mathrm{~m}^{-2 *} \mathrm{~d}^{-1}$. Conducted studies show that methane and carbon dioxide emission are low in the studied area. It does not confirm the elevated values of light hydrocarbons and associated components which were previously recorded in the soil gas samples.
\end{abstract}

\section{Introduction}

The surface geochemical survey are among unconventional measurements methods used mostly for hydrocarbon prospection and environmental protection. For many years now, the Outer Carpathians have been an area of the studies on the effects of hydrocarbons penetration from deep-seated accumulations and the zones of their generation to the land surface. Migration of hydrocarbons from deep accumulations towards the surface is controlled by diffusion and effusion. The effects of these processes are referred to as microseepage [1, 2]. Such phenomena still exist in the Carpathians [3]. In the past, hydrocarbon's seepages were used as direct indicators of the occurrence of subsurface accumulations of oil and gas. The hydrocarbon seepages are typical of petroleum basins of complicated tectonics and are observed mostly in the elevated, axial zones of fold structures, and in dislocation zones [3, 4].

\footnotetext{
* Corresponding author: agora@agh.edu.pl
} 
The following paper aims to estimate the quantify of methane and carbon dioxide emissions from the soil to the atmosphere in the selected area of the Polish Western Carpathians.

The basic materials and results were presented in MSc. Eng. project prepared by one of the authors [5].

\section{Location of study area}

The study area is located in the western part of the Outer Carpathians. The measuring points were arranged within the range of the occurrence of three litho-stratigraphic units: Magura, Fore-Magura and Silesian units. These units differ from each other in terms of the development, formations age and the tectonic style.

For gas sampling, ten sites were selected to carry out emission measurement (Fig. 1). They were located along the geochemical profile where soil gas samples had been taken [6]. Methane concentrations in soil gas samples ranged from 2,05 to 37,96 ppm, whereas carbon dioxide from 0,091 to 0,842 vol.\%. At locations where inside soil gas samples elevated levels of methane and/or carbon dioxide were detected, emission measurements were made. The second criterion for the selection of emission measuring points were a 100 $\mathrm{ml}$ volume of the soil gas samples taken during the geochemical sampling, which indicated the good permeability of the soil at the gas sampling depth of $1.2 \mathrm{~m}$.

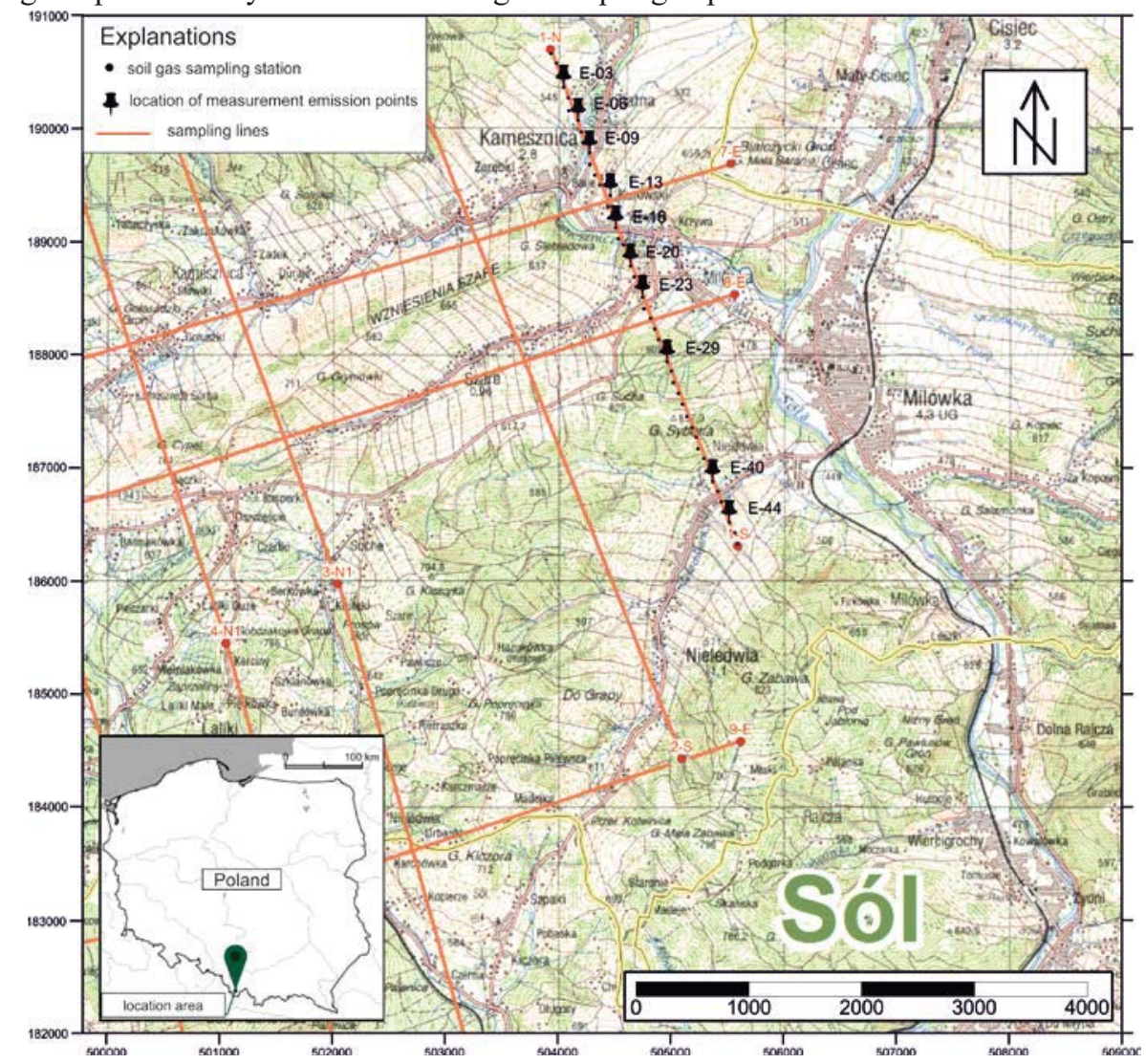

Fig. 1. Location of the soil gas and emission sample stations. 


\section{Methodology}

\subsection{Field sampling}

In the field, the measurement of emission was performed in two variants: natural emission (on the surface of terrain) and with excluding of near-surface zone (with an additional hole). The patented static chamber method was applied [7]. This method is commonly used in the near-surface geochemical survey for determination the gas release from Earth to the atmosphere.

The hole simulates a disruption of the continuity of the layers of rock, which allows for the examination of uncontrolled flow of gas into a closed space. In the case of the measurement of the emission on the land surface without the hole, it is possible to estimate only the amount of methane that has not undergone bacterial destruction and being released into the atmosphere [1]. It is assumed that - depending on the environmental conditions the largest activity of methanotrophic bacteria occurs up to the depth of approximately 0.8 $\mathrm{m}$ [8]. This stratum is considered by some researchers to be a sort of "bacterial filter", that may significantly reduce or completely eliminate the release of methane into the atmosphere [9].

In general, the method applied in the field involves a collection of gas samples from the inner space of closed and sealed chamber adjacent to the land surface in predefined time intervals. The static chamber method does not involve air flow into the chamber. The chamber itself is a vessel of volume $10.8 \mathrm{dm}^{3}$ made of stainless steel and it is provided with a sealed opening to allow a sample of gas from the interior volume of the chamber (Fig. 2). The area directly covered by the chamber is $7.1 \mathrm{dm}^{2}$.
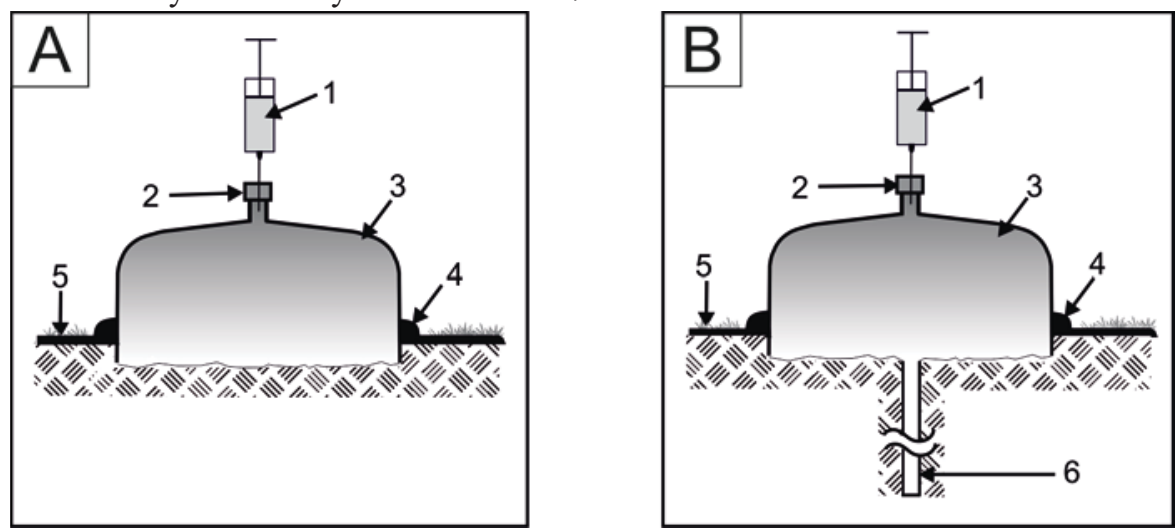

Fig. 2. Measurement methods for natural emission (A) and with the use of a well (B): 1 - gas tight syringe, 2 - rubber diaphragm, 3 - cap of the static chamber, 4 - seal, 5 - land surface, 6 - well.

Before the installation of the chamber, a hole was drilled up to the depth of approximately $0.5 \mathrm{~m}$ using a tube with a $40 \mathrm{~mm}$ diameter (Fig. 2). The side surface of the $100 \mathrm{~cm} \times 3.14$ $\mathrm{cm}$ cylinder created by the hole formed an additional emission surface, which was included in the calculations. Additionally, contact between chamber edge and soil was sealed. Afterwards, at each site, gas was sampled immediately after chamber setting, then after 10, 20 and 30 minutes. During the sampling, the atmospheric pressure was measured together with soil temperature at $10 \mathrm{~cm}$ depth. Samples of $50 \mathrm{ml}$ were pumped to special glass vessels filled with brine. Totally, 40 gas samples were collected from 10 sampling sites. 


\subsection{Analytical procedure}

Gas samples collected from static chamber method were taken to the laboratory and analyzed using gas chromatography. The analyses of gas samples were focused on detection of methane and its higher homologues (ethane, propane, i-butane, n-butane) as well as on gaseous alkenes (ethylene, propylene, 1-butene) and carbon dioxide. Analyses were carried out at the Department of Fossil Fuels, AGH University of Science and Technology in Kraków with a FISSONS Instruments GC 8160 gas chromatograph equipped with a FID and CARLO ERBA Instruments GC 6300 gas chromatograph equipped with a thermal-conductivity detector (TCD).

First instruments used a metal column (internal diameter $4 \mathrm{~mm}$, length $1.3 \mathrm{~m}$ ) filled with Activated Alumina (mesh 100/120). The carrier gas (He) flow rate was $60 \mathrm{ml} / \mathrm{min}$. The programmed column temperatures were: $80^{\circ} \mathrm{C}$ for $3 \mathrm{~min}, 80-200^{\circ} \mathrm{C}$ increment at $30^{\circ} \mathrm{C} / \mathrm{min}$ rate and $200^{\circ} \mathrm{C}$ for $3 \mathrm{~min}$. The FID working temperature was $270^{\circ} \mathrm{C}$, the injection chamber temperature was $120^{\circ} \mathrm{C}$ and the volume of each injected sample was $2 \mathrm{ml}$.

The analyses of $\mathrm{CO}_{2}$ were carried out with a TCD detector. The following analytical conditions were applied: metal columns (internal diameter $4 \mathrm{~mm}$, length $1.5 \mathrm{~m}$ ) filled with the HaySep; carrier gas (Ar) flow rate $30 \mathrm{ml} / \mathrm{min}$; constant column temperature: $65^{\circ} \mathrm{C}$, TCD detector temperature $60^{\circ} \mathrm{C}$, TCD filament temperature $260^{\circ} \mathrm{C}$ and volume of sample was 2 $\mathrm{ml}$ injected with an automatic valve.

Both the FID and TCD readings were processed with the Peak Simple integration program. The gas chromatograph was calibrated with „Scott II” gas standard distributed by the Supelco and Alltech. Precision was estimated at 5\% of measured values.

\subsection{Methodology of emission calculation}

The quantities of methane and carbon dioxide emissions were calculated using the formula established during the previous geochemical surveys [10].

$$
\begin{aligned}
& E^{C H_{4}}=\frac{V_{p}}{A} \cdot \frac{M_{W} \cdot T_{0} \cdot p}{M_{V} \cdot p_{0} \cdot\left(T_{0}+t_{g l}\right)} \cdot n^{C H_{4}} \\
& E^{C O_{2}}=\frac{V_{p}}{A} \cdot \frac{M_{W} \cdot T_{0} \cdot p}{M_{V} \cdot p_{0} \cdot\left(T_{0}+t_{g l}\right)} \cdot n^{C O_{2}}
\end{aligned}
$$

where:

$\mathrm{E}^{\mathrm{CH} 4}-$ emission of $\mathrm{CH}_{4}\left(\mathrm{~g} * \mathrm{dm}^{-2 *} \min ^{-1}\right)$;

$\mathrm{E}^{\mathrm{CO} 2}-$ emission of $\mathrm{CO}_{2}\left(\mathrm{~g}^{*} \mathrm{dm}^{-2 *} \mathrm{~min}^{-1}\right)$;

$\mathrm{M}_{\mathrm{W}}-$ molecular weight (for $\mathrm{CH}_{4}: M_{W}=16 \mathrm{~g}$, for $\mathrm{CO}_{2}: M_{W}=44 \mathrm{~g}$ );

$\mathrm{M}_{\mathrm{V}}$ - volume of 1 moles of gas in normal conditions $\left(p_{0}=1013 * 10^{2} \mathrm{~Pa}, T_{0}=273{ }^{\circ} \mathrm{K}\right)\left(M_{V}=\right.$ $\left.22,4 \mathrm{dm}^{3}\right)$

$\mathrm{t}_{\mathrm{gl}}$ - soil temperature $\left({ }^{\circ} \mathrm{C}\right),\left(T_{0}=273{ }^{\circ} \mathrm{K}\right)$;

$\mathrm{p}$ - atmospheric pressure $(\mathrm{Pa})$;

$\mathrm{V}_{\mathrm{P}} / \mathrm{A}$ - chamber parameter $\left(V_{p}-\right.$ volume $\left[\mathrm{dm}^{3}\right], A$ - surface of emission $\left.\mathrm{dm}^{2}\right)$;

$\mathrm{n}^{\mathrm{CH} 4}=\mathrm{dc} / \mathrm{dt}$ for $t \rightarrow 0\left(\mathrm{CH}_{4}\right.$ concentrations rise rate in the chamber $\left(\mathrm{ppm}^{*} \mathrm{~min}^{-1}\right)$ obtained from the concentration rise function);

$\mathrm{n}^{\mathrm{CO} 2}=\mathrm{dc} / \mathrm{dt}$ for $t \rightarrow 0\left(\mathrm{CO}_{2}\right.$ concentrations rise rate in the chamber $\left(\right.$ vol. $\left.\% * \mathrm{~min}^{-1}\right)$ obtained from the concentration rise function). 
The values of the soil temperature and atmospheric pressure in the relations (1) and (2) were used as averaged values from the measurements taken during sampling. This was due to the small variability range of the measured values.

The calculated values of the changes in methane concentrations were given in ppm per hour $[\mathrm{ppm} / \mathrm{h}]$ and carbon dioxide in vol.\% per hour $[\mathrm{vol} . \% / \mathrm{h}]$. These values were summarized in tables (Table 1,2). The tables also contain the methane and carbon dioxide emission $\left(\mathrm{E}^{\mathrm{CH} 4}, \mathrm{E}^{\mathrm{CO} 2}\right)$. Their values were given in milligrams per square meter per day

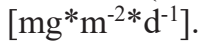

\section{Results and discussion}

\subsection{Results of natural emission}

The dynamics of the changes in the concentrations of methane naturally escape from nearsurface zone to the atmosphere $\left(\mathrm{n}^{\mathrm{CH} 4}\right)$ is determined by the range from -0.846 to 0.204 $\mathrm{ppm} / \mathrm{h}$. The decreasing trends were observed at all locations (Tab. 1). The natural methane emission values are negligible and range from -1.469 to $0.354 \mathrm{mg}^{*} \mathrm{~m}^{-2 *} \mathrm{~d}^{-1}$. Only two measuring points recorded positive values. (Tab. 1). The positive emission indicates that methane is continuously released to the atmosphere, while the negative emission are the result of bacterial destruction of this gas in the near-surface zone.

The dynamics of the changes in carbon dioxide concentrations varies from -0.101 to $0.120 \mathrm{vol} . \% / \mathrm{h}$. In $20 \%$ of sampling sites, the decreasing trends were observed (Tab.1). The natural carbon dioxide emission values are between -4812.8 and $5658.7 \mathrm{mg}^{*} \mathrm{~m}^{-2 *} \mathrm{~d}^{-1}$. Two measuring points recorded negative values, which may be related to an inflow of air into the chamber. However, positive emission values are predominant, represents a transfer from soil to the atmosphere.

Table 1. Values of changes of methane and carbon dioxide concentration and natural emission calculated on the basis of measurements with application of the static chamber method.

\begin{tabular}{|c|c|c|c|c|c|}
\hline \multirow{2}{*}{$\begin{array}{c}\text { Item } \\
\text { number }\end{array}$} & \multirow{2}{*}{$\begin{array}{c}\text { Number } \\
\text { of site }\end{array}$} & \multicolumn{2}{|c|}{ METHANE } & \multicolumn{2}{|c|}{ CARBON DIOXIDE } \\
\hline & & $\begin{array}{c}\text { Change of } \\
\text { concentration } \\
n^{C H_{4}} \\
(\mathrm{ppm} / \mathrm{h})\end{array}$ & $\begin{array}{c}\begin{array}{c}\text { Value of } \\
\text { methane } \\
\text { emission }\end{array} \\
E^{C H_{4}} \\
\left(\mathrm{mg}^{*} \mathrm{~m}^{-2 *} \mathrm{~d}^{-1}\right)\end{array}$ & $\begin{array}{c}\text { Change of } \\
\text { concentration } \\
n^{\mathrm{CO}_{2}} \\
(\mathrm{vol} . \% / \mathrm{h})\end{array}$ & $\begin{array}{c}\text { Value of carbon } \\
\text { dioxide emission } \\
E^{C O_{2}} \\
\left(\mathrm{mg}^{*} \mathrm{~m}^{-2 *} \mathrm{~d}^{-1}\right)\end{array}$ \\
\hline 1 & E-3N & -0.846 & -1.469 & -0.101 & -4812.8 \\
\hline 2 & E-6N & -0.204 & -0.355 & 0.080 & 3845.4 \\
\hline 3 & E-9N & 0.204 & 0.354 & -0.011 & -543.5 \\
\hline 4 & E-13N & 0.168 & 0.288 & 0.120 & 5658.7 \\
\hline 5 & E-16N & -0.204 & -0.355 & 0.053 & 2554.1 \\
\hline 6 & E-20N & -0.336 & -0.579 & 0.053 & 2501.0 \\
\hline 7 & E-23N & -0.216 & -0.370 & 0.004 & 168.2 \\
\hline 8 & E-29N & -0.708 & -1.216 & 0.040 & 1871.1 \\
\hline 9 & E-40N & -0.426 & -0.731 & 0.064 & 3030.3 \\
\hline 10 & E-44N & -0.042 & -0.072 & 0.086 & 4020.4 \\
\hline
\end{tabular}




\subsection{Results of emission with an additional hole}

The dynamics of concentrations changes of methane $\left(\mathrm{n}^{\mathrm{CH} 4}\right)$ after making an additional hole, is expressed by the range from -0.750 to $0.390 \mathrm{ppm} / \mathrm{h}$. In $60 \%$ of sampling points, decreasing trends were found (Tab. 2). The methane emission values calculated based on the static chamber method with application of the hole are very similar to the natural emission values and is illustrated by values from -1.133 to $0.316 \mathrm{mg}^{*} \mathrm{~m}^{-2 *} \mathrm{~d}^{-1}$.

The dynamics of the changes in carbon dioxide concentrations from the drilled hole ranges from $-0,083$ to $0,111 \mathrm{vol} . \% / \mathrm{h}$. Carbon dioxide showed emission values from 3432,5 to $4657,9 \mathrm{mg}^{*} \mathrm{~m}^{-2 *} \mathrm{~d}^{-1}$. The reduction of the emission values after making the hole may be due to the fact that carbon dioxide, which is heavier than the air, may fall gradually during the measurement onto the bottom of the drilled well.

The calculated values of natural emission and with excluding of near-surface zone are comparable to the values obtained in different areas by other researchers, including in the Carpathians $[2,10,11]$.

Table 2. Values of changes of methane and carbon dioxide concentration and emission with an additional well calculated on the basis of measurements with application of the static chamber method.

\begin{tabular}{|c|c|c|c|c|c|}
\hline \multirow{2}{*}{$\begin{array}{c}\text { Item } \\
\text { number }\end{array}$} & \multirow{2}{*}{$\begin{array}{c}\text { Number } \\
\text { of site }\end{array}$} & \multicolumn{2}{|c|}{ METHANE } & \multicolumn{2}{|c|}{ CARBON DIOXIDE } \\
\hline & & $\begin{array}{c}\text { Change of } \\
\text { concentration } \\
n^{\mathrm{CH}_{4}} \\
(\mathrm{ppm} / \mathrm{h})\end{array}$ & $\begin{array}{c}\begin{array}{c}\text { Value of } \\
\text { methane } \\
\text { emission }\end{array} \\
E^{C H_{4}} \\
\left(\mathrm{mg}^{*} \mathrm{~m}^{-2 *} \mathrm{~d}^{-1}\right)\end{array}$ & $\begin{array}{c}\text { Change of } \\
\text { concentration } \\
n^{C O_{2}} \\
(\mathrm{vol} . \% / \mathrm{h})\end{array}$ & $\begin{array}{c}\begin{array}{c}\text { Value of carbon } \\
\text { dioxide emission }\end{array} \\
E^{C O_{2}} \\
\left(\mathrm{mg}^{*} \mathrm{~m}^{-2 *} \mathrm{~d}^{-1}\right)\end{array}$ \\
\hline 1 & E-3W & -0.072 & -0.110 & -0.080 & -3342.8 \\
\hline 2 & E-6W & -0.372 & -0.568 & 0.111 & 4657.9 \\
\hline 3 & E-9W & 0.390 & 0.032 & 0.025 & 55.3 \\
\hline 4 & E-13W & 0.210 & 0.316 & 0.060 & 2482.3 \\
\hline 5 & E-16W & 0.060 & 0.092 & -0.054 & -2266.0 \\
\hline 6 & E-20W & -0.750 & -1.133 & 0.043 & 1795.3 \\
\hline 7 & E-23W & 0.246 & 0.020 & -0.043 & -94.6 \\
\hline 8 & E-29W & -0.582 & -0.877 & -0.083 & -3432.5 \\
\hline 9 & E-40W & -0.474 & -0.714 & 0.050 & 2062.3 \\
\hline 10 & E-44W & -0.444 & -0.664 & -0.014 & -592.0 \\
\hline
\end{tabular}

\section{Conclusion}

The sampling sites were situated at locations where previously in soil-gas samples have been detected elevated levels of methane and/or carbon dioxide as well as the presence of higher homologues of methane, denoting to their deep-seated origin. Totally, ten points were selected for sampling. Emission measurements using the method of static chambers were conducted (PL 206259 B1 patent [7]). Changes in the concentrations of methane and carbon dioxide released naturally to the land surface, as well as from the depth of $0.5 \mathrm{~m}$ were measured. Due to the fact that the measurements were taken within a short period of time the seasonal changes could not have had any influence on the established emission value.

The natural methane emission measurements ranged from -1.469 to $0.354 \mathrm{mg}^{*} \mathrm{~m}^{-2 *} \mathrm{~d}^{-1}$. The performed emission measurements indicate that the study area is dominated by negative $\mathrm{CH}_{4}$ emission values. This may be evidence of microbial assimilation process of 
hydrocarbons occurring in the soil. Similar values are observed after making a hole ranging from -1.133 to $0.316 \mathrm{mg}^{*} \mathrm{~m}^{-2 *} \mathrm{~d}^{-1}$. The changes of the natural carbon dioxide emissions ranged from -4812.8 to $5658.7 \mathrm{mg}^{*} \mathrm{~m}^{-2 *} \mathrm{~d}^{-1}$. The variability range for the emissions of carbon dioxide with an additional hole is smaller and is illustrated by values from -3432.5 to $4657.9 \mathrm{mg}^{*} \mathrm{~m}^{-2 *} \mathrm{~d}^{-1}$. However, the drilling of the well increased the percentage share of the measuring points with a negative $\mathrm{CO}_{2}$ value. The obtained results indicate a small intensity of the inflow of methane and carbon dioxide into the near-surface zone. Moreover, negligible emission values, that not confirm elevated methane and carbon dioxide concentrations recorded in soil gas samples may be due to a too shallow hole. The emission was measured over a hole, which was drilled up only to the depth of approximately $0.5 \mathrm{~m}$, but the samples of the soil gas were collected at a depth of $1.2 \mathrm{~m}$. Therefore, we believe that the hole should be drilled below the active exchange zone (at least $1 \mathrm{~m}$ ).

Conducted studies show that methane and carbon dioxide emission from soil to the atmosphere are low in the studied area. It does not confirm the elevated values of light hydrocarbons and associated components which were previously recorded in the soil gas samples. This indicates low activity of gases migrating from the depths. The negative values of methane emission may also be evidence that processes of methanotrophic methane oxidation are active in the near-surface zone.

The research was funded as a part of the Project of the National Centre for Research and Development Blue Gas (BG2/ShaleCarp/14).

\section{References}

1. G. Etiope, R.W. Klusman, Chemosphere, 49, 777-789 (2002)

2. G. Etiope, Atmos. Environ., 43, 1430-1443 (2009)

3. J. Kuśmierek, G. Machowski, Pr. Inst. Nafty i Gazu, 150, 247-250 (2008)

4. D.F. Saunders, K.R. Burson, C.K. Thompson, AAPG Bull, 83, 1 (1999)

5. M. Mojżysz, Master thesis. Arch. Fac. of Geology Geophysics and Environmental Protection, AGH University of Science and Technology (2017)

6. M. Dzieniewicz, H. Sechman, no. 184080, WUP, 08/08 (2002)

7. A. Korus, M.J. Kotarba, M. Dzieniewicz, H. Sechman, no. 206259 B1, WUP, 07/10 (2010)

8. W.J.H. Kunicki-Goldfinger, Życie bakterii (PWN, 1994)

9. R.W. Klusman, AAPG Bull., 89, 8 (2005)

10. H. Sechman, M. Dzieniewicz, Geology., 35, 129-153 (2008)

11. J. Tang, Z. Bao, W. Xiang, Q. Gou, J Environ Sci, 20, 1055-1062 (2008) 